LIMA, TJL; GAZAFFI, R; CECCHERINI, GJ; MARCHI, L; MARTINEZ, M; FERREIRA, CG; SALA, FC. 2018. Volume of cells on trays influences hydroponic lettuce production. Horticultura Brasileira 36: 408-413. DOI - http://dx.doi.org/10.1590/S0102-053620180320

\title{
Volume of cells on trays influences hydroponic lettuce production
}

\author{
Tiago JL Lima; Rodrigo Gazaffi; Guilherme J Ceccherini; Luana Marchi; Marcela Martinez; Camila G \\ Ferreira; Fernando C Sala ${ }^{1}$
}

${ }^{1}$ Universidade Federal de São Carlos (UFSCar), Araras-SP, Brazil; tiagoxleme@hotmail.com; rgazaffi@ufscar.br; gui.ceccherini@hotmail. com; luana.marchi@hotmail.com; marcela.ciarlomartinez@hotmail.com; camilagaby@gmail.com; fcsala@ufscar.br

\begin{abstract}
Lettuce seedlings used on hydroponic cultivation (NFT) are usually produced in trays with small volume, requiring two transplants: from tray to nursery and then to the definitive place. The aim of this study was to verify lettuce performance under NFT system, using seedlings produced in trays with several cell volumes $\left(50,40,35,31,30,29,27,20\right.$ and $\left.10 \mathrm{~cm}^{3} \mathrm{cell}^{-1}\right)$. The tray volumes are considered treatments. The experimental design was completely randomized blocks, with four replicates. Seedlings were transplanted directly to the definitive profile, except those ones produced in $10 \mathrm{~cm}^{3}$ cell $^{-1}$. Two harvests were performed, at 22 and 29 days after transplant (DAT). We evaluated number of senescent leaves, total number of leaves, shoot fresh mass, root fresh mass, shoot dry mass, stem length and productivity. The best performance was obtained using seedlings produced in trays with higher volume per cell. The nursery phase was not necessary and it was possible to obtain reduction from two to one transplant, corresponding to trays of 20 to $50 \mathrm{~cm}^{3} \mathrm{cell}^{-1}$. Seedlings produced in trays with 40 and $50 \mathrm{~cm}^{3}$ cell-1 made the early harvest possible, at 22 DAT of cultivation under hydroponic NFT system.
\end{abstract}

Keywords: Lactuca sativa, seedlings, tray, soilless cultivation, hidroponic.

\section{RESUMO}

Volume das células em bandejas influencia produção da alface hidropônica

Tem-se produzido mudas de alface em bandejas cujas células são de pequeno volume para posterior utilização na produção hidropônica. Dessa forma, dois transplantes são necessários, da bandeja para o berçário e posteriormente ao definitivo. $\mathrm{O}$ objetivo desta pesquisa foi verificar o desempenho de alface em NFT utilizando mudas produzidas em diversos volumes de células de bandejas $(50,40,35$, $31,30,29,27,20$ e $10 \mathrm{~cm}^{3}$ célula $\left.{ }^{-1}\right)$, constituindo os tratamentos. $\mathrm{O}$ delineamento experimental foi blocos inteiramente casualizados com quatro repetições. As mudas foram transplantadas diretamente na fase definitiva, exceto as de $10 \mathrm{~cm}^{3}$ célula $^{-1}$. Foram realizadas duas colheitas, aos 22 e aos 29 dias após o transplante (DAT). Avaliaram-se número de folhas em senescência, total de folhas, massa fresca da parte aérea, massa fresca da raiz, massa seca da parte aérea, comprimento do caule e produtividade. O melhor desempenho foi das mudas produzidas em bandejas com maior volume por célula. Dispensou-se a fase de berçário e foi possível obter a redução de transplante de dois para um nos tratamentos correspondentes às bandejas de 20 a $50 \mathrm{~cm}^{3}$ célula ${ }^{-1}$. A produção de mudas em bandejas com 40 e $50 \mathrm{~cm}^{3}$ célula-1 possibilitou colheita precoce aos 22 DAT de cultivo no sistema hidropônico NFT.

Palavras chave: Lactuca sativa, muda, bandeja, cultivo sem solo, hidroponia.

Received on March 14, 2017; accepted on April 17, 2018

$\mathrm{I}^{\mathrm{n}}$ $\mathrm{n}$ Brazil, around 2,000 hectares of food crops are grown under hydroponic systems, and the state of São Paulo stands out as the leading producer. One in five Brazilian municipalities practices hydroponic cultivation (APTA, 2014), considering lettuce the predominant vegetable grown under hydroponic NFT system: Grand Rapids type, followed by crisphead lettuce, looseleaf type and other varieties (Sala \& Costa, 2012).

Hydroponic cultivation has boosted several sectors, such as seedling production. Good quality seedlings can influence the final success of the crop, improving sanitary aspect, operational efficiency, earliness and quality of harvested products (Minami, 2010). Seedlings should have suitable physiological characteristics for different production processes which will be submitted after transplanting.

Vegetable seedling production is characterized by numerous models of existing trays, with quantity, volume, depth and different cell shape (Filgueira, 2008).

In Brazil, lettuce cultivation under NFT system commonly uses seedlings produced in trays of 200 cells ( 10 to 12 $\mathrm{cm}^{3}$ cell ${ }^{-1}$ ), containing less volume of substrate in its cell and consequent lower seedling development (Menezes Junior et al., 2000). Seedlings of this kind of tray normally need two transplants under hydroponic system, from tray to intermediate phase, in which they will spend about 7 to 12 days on benches consisting of smaller profiles. Then, from intermediate phase to definitive phase, which consists of bigger profiles; where they will develop until reaching harvest time. The small size of seedlings produced in $10 \mathrm{~cm}^{3}$ cell-1 trays makes impossible the direct transplant for 
definitive phase. The definitive phase is characterized by profiles of bigger size, which will not remain adequately at the transplant site.

Higher number of transplants under NFT system results in damage to roots and shoots, causing stress in plants and consequently an increase in production costs due to losses and developmental delay, as well as greater use of labor, longer crop cycle and greater space occupied by the intermediate phase benches.

Seedlings produced in trays with larger volume cell may provide more developed lettuce adult plants, eliminating the intermediate phase. When roots have free development, they double its length, considering that the explored space will be eight times larger (Primavesi, 2002). Seedlings could be transplanted directly to the definitive phase of the hydroponic system, considering that plants from trays can show good adaptation to the new environment, higher resistance to mechanic damage during transplant, growing time reduction and, consequently, cost reduction (Reghin et al., 2007, Maggioni, 2014). The aim of this study was to evaluate the performance of lettuce grown under NFT system using seedlings produced under different cell volumes.

\section{MATERIAL AND METHODS}

Seedlings were produced in a commercial nursery (IBS Mudas), located in Piracicaba, from February 3 to March 13, 2016 (2237'46" S $47^{\circ} 36^{\prime} 07^{\prime \prime} \mathrm{W}, 547 \mathrm{~m}$ altitude). Nine volumes differentiated per tray cell for seedling production were used $(50,40,35,31,30,29,27,20$ and 10 $\mathrm{cm}^{3}$ cell $^{-1}$ ) (Table 1). The experimental design was completely randomized blocks, with four replicates, 45 plants each. Pelleted lettuce seeds, cv. Vanda (Sakata) were sown, each cell receiving one seed. Coconut fiber was used as substrate (Amafibra). After sowing, trays were kept in a germination room with controlled environment $\left(25^{\circ} \mathrm{C}\right.$ and $80 \%$ relative humidity) for 48 hours. Right after, for seedling development, trays were allocated in an arch type greenhouse (100 m length, $10 \mathrm{~m}$ wide and $4 \mathrm{~m}$ ceiling height). Trays were placed on $0.50 \mathrm{~m}$ benches. Lateral and front walls were made of anti-aphid screens, using polyethylene film, 150 $\mu \mathrm{m}$ and concrete floor. Irrigation and fertigation were done using sprinkler irrigation system with mobile bars. Seedlings were kept in a protected environment for 40 days, being transplanted after this period.

Seedlings were transplanted into NFT system, 39 days after sowing (DAS) in an experimental area of Universidade Federal de São Carlos, in Araras-SP $\left(22^{\circ} 21^{\prime} 25^{\prime}\right.$ 'S, 47 $23^{\circ} 03^{\prime}$ 'W, $646 \mathrm{~m}$ altitude). Seedlings were transplanted directly to definitive phase, except of volume $10 \mathrm{~cm}^{3}$ cell- $^{-1}$. These seedlings remained in intermediate phase for 10 days until appropriate size for transplant to definitive phase. The structure of the definitive phase consisted of a self-priming pump (1 hp engine, maximum flow of $3600 \mathrm{~L}$ hour $\left.^{-1}\right), 5000$ liter capacity reservoir, red screen covering ( $30 \%$ shading), $40 \mathrm{~m}$ long lateral walls covered with red roof (40 m long, $48 \mathrm{~m}$ wide, 1.95 $\mathrm{m}$ height ceiling). On the definitive phase we used four benches with seven $75 \mathrm{~mm}$ profiles $(7.5 \mathrm{~cm}$ height, $10 \mathrm{~cm}$ wide) with $15 \mathrm{~m}$ in length and spacing of $0.30 \mathrm{~m}$ between profiles and $0.25 \mathrm{~m}$ between plants. Bench slope of $6 \%$ and intermediate phase corresponded to a pump and a $500 \mathrm{~L}$ capacity reservoir, profiles of $35 \mathrm{~mm}(5 \mathrm{~cm}$ height, $7 \mathrm{~cm}$ width), spacing $0.10 \mathrm{~m}$ between plants and $0.15 \mathrm{~m}$ between profiles, width of $15 \mathrm{~m}$, slope of $6 \%$, red screen covering (30\% shading) and lateral walls also composed of the same material.

Nutrient solution (Furlani, 1999) was used both for plants in intermediate and in definitive phase. The circulation scheme of nutrient solution was every 15 minutes during the day (from 6 a.m. to 6 p.m.) and 15 minutes every 4 hours during night. Nutrient solution flow in the hydroponic system was adjusted to $1.8 \mathrm{~L}$ per minute per profile in the definitive system and, in the intermediate phase, to $0.5 \mathrm{~L}$ per minute per profile. The values of $\mathrm{pH}$ and electrical conductivity were controlled daily, from 5.5 to 6.5 and from 1.6 to 1.7 , respectively, from transplant to harvest, both for intermediate and definitive phase.

Pests and diseases were controlled preventively, applying Benevia (Dupont, Cyantraniliprole) at a dose of $1 \mathrm{~g} \mathrm{~L}^{-1}$ and Serenade $\left(2.8 \mathrm{~mL} \mathrm{~L}^{-1}\right)$ (Basf, Bacillus subtilis lineage QST 713) at 13 days.

Two harvests were performed, eight plants at each harvest. The first harvest, at 22 days after transplant (DAT), and the second, at 29 DAT. The following traits were evaluated: total number of leaves per plant, shoot fresh mass, root fresh mass, shoot dry mass, stem length, productivity, number of leaves during senescence (leaves which are not commercially acceptable and present yellow color). Leaves during senescence were evaluated only at the 29 DAT harvest, since no leaf was senescent at 22 DAT.

Two harvest seasons were analyzed, using split-plot model. However, aiming to study the relation existing between volume and other traits studied for each of the seasons, the authors adopted the following hierarchical model:

$$
Y_{i j k}=\mu+C_{k}+C V_{i k}+e_{i j k}
$$

in which, $Y_{i j k}$ corresponds to the observed variable; $\mu$ is the overall average; $C_{k}$ is the harvest effect; $C V_{i k}$ is the nested effect of volume $i$ within each of the cuts; $e_{i j k}$ is the experimental mistake (Gomes, 2009). When effect of volume within harvest seasons was significant, the authors searched to identify the best polynomial regression model in order to interpret the phenomenon. To make the interpretation easier, first, second and third degree models were considered and tested sequentially. Analyses were done using the statistical software $R$ ( $R$ Core Team, 2015), especially the ExpDes package (Ferreira et al., 2013).

\section{RESULTS AND DISCUSSION}

We observed an increase of 0.75 senescent leaves with an increase of $10 \mathrm{~g}$ of cell volume. Using the smallest cell volume $\left(10 \mathrm{~cm}^{3}\right)$, lettuce produced 1.9 senescent leaves plant ${ }^{-1}$ at 29 DAT 
whereas, in the trays from 29 to $50 \mathrm{~cm}^{3}$ cell $^{-1}$, lettuce produced from 3.18 to 4.65 senescent plant ${ }^{-1}$ (Figure 1A). Senescent leaves are removed from the plant (toilet) before wrapping them in plastic bags for commercialization. The greater the number of these leaves the greater the time required for this activity. Lettuce obtained in trays with larger cell volume need more toilet, compared with lettuce growing in trays with $10 \mathrm{~cm}^{3}$ cell $^{-1}$. The leaves at the base of the plants

Table 1. Volume per cell (VPC), number of cells (NC), depth (P), tray area (AB), and cell shape (CS) on styrofoam trays. Araras, UFSCar, 2016.

\begin{tabular}{lrccc}
\hline $\mathbf{V P C}\left(\mathbf{c m}^{\mathbf{3}}\right)$ & $\mathbf{N C}$ & $\mathbf{P}(\mathbf{c m})$ & $\mathbf{A B}\left(\mathbf{c m}^{2}\right)$ & $\mathbf{C S}$ \\
\hline 50 & 72 & 6.0 & 13.7 & Conical \\
40 & 64 & 5.0 & 22.7 & Cube \\
35 & 84 & 4.0 & 15.6 & Cube \\
31 & 162 & 5.5 & 22.7 & Pyramidal \\
30 & 98 & 5.5 & 13.5 & Conical \\
29 & 64 & 6.0 & 11.5 & Pyramidal \\
27 & 128 & 4.0 & 13.5 & Cube \\
20 & 128 & 4.5 & 13.5 & Pyramidal \\
10 & 200 & 4.0 & 13.5 & Pyramidal \\
\hline
\end{tabular}

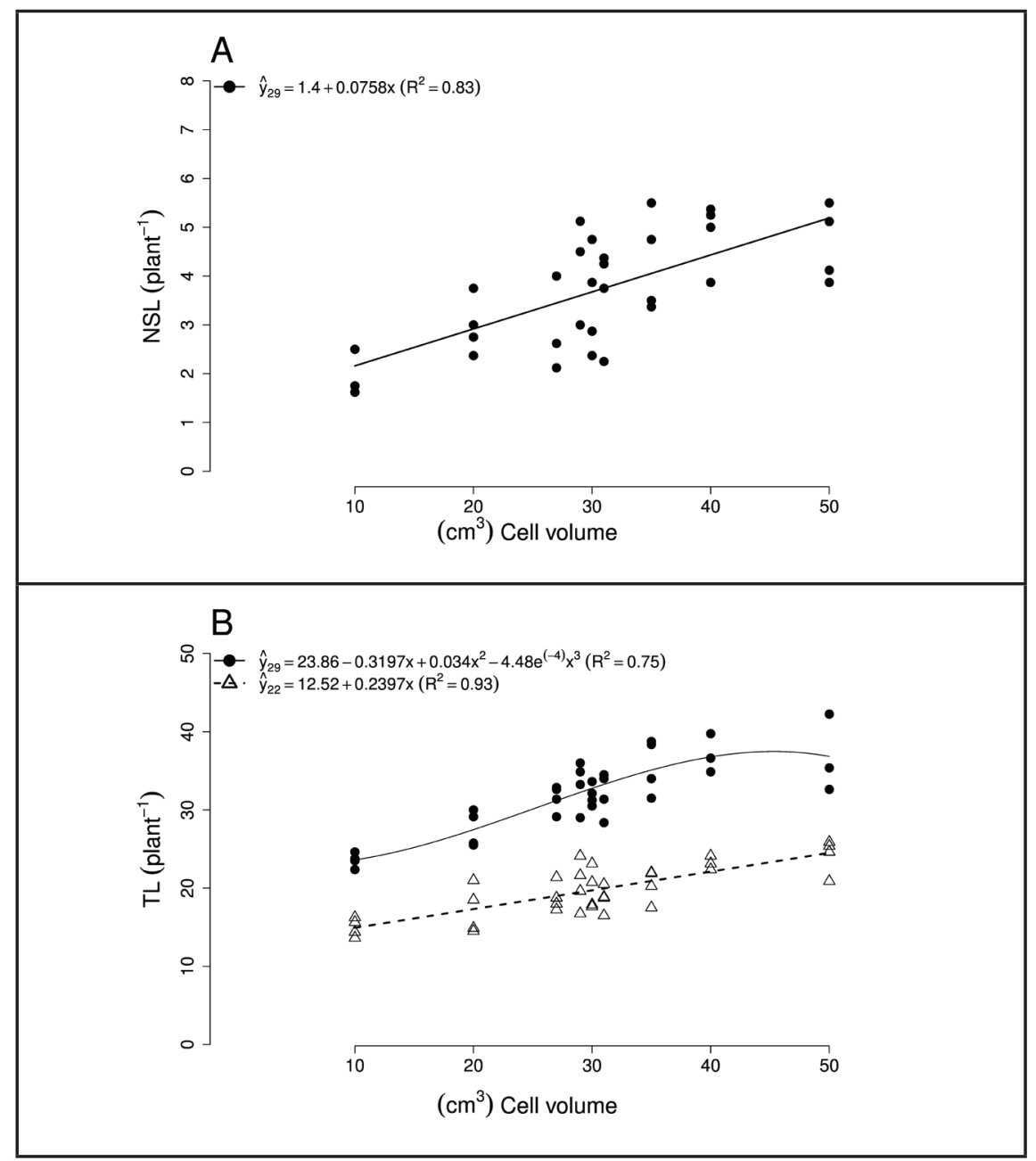

Figure 1. $A=$ Number of senescent leaves $\left(N S L\right.$ plant $\left.{ }^{-1}\right)$ and $B=$ Total leaves $\left(\right.$ TL plant $\left.{ }^{-1}\right)$ of lettuce plants harvested at 22 and 29 DAT, grown in NFT hydroponic system using seedlings produced in trays with different volumes per cell. Araras, UFSCar, 2016.

from larger cell volumes were shaded by the upper ones which interrupted most of the incident solar energy; thus, according to Campos-Vargas \& SaltVeit (2002), favoring the accumulation of phenolic compounds responsible for the induction of yellowing and subsequent death of lower leaves, probably due to spacing which became denser by the development of these lettuces at 29 DAT. Similar situation was found in lettuce seedlings produced in trays with 128 cells and transplanted into soil at different ages, in which older plants tended to an increase of senescent leaves in relation to their better growth (Andriolo et al., 2003).

Total number of leaves increased constantly according to the range of cell volume variation. At 29 DAT, total number of leaves increased considerably on lettuce produced in trays with cells of up to $30 \mathrm{~cm}^{3}$, being the maximum in trays with volumes of 40 and $50 \mathrm{~cm}^{3}$. In the two harvests, smaller quantities of leaves per plant were found in plants produced in trays with volumes of 20 and $10 \mathrm{~cm}^{3} \mathrm{cell}^{-1}$. In the first harvest, we noticed $61.9 \%$ more leaves in plants produced from the greater $\left(50 \mathrm{~cm}^{3} \mathrm{cell}^{-1}\right)$ to the lower volume $\left(10 \mathrm{~cm}^{3} \mathrm{cell}^{-1}\right)$ and $62.8 \%$ in the second harvest, showing similar plant growth in the two harvests (Figure 1B). Growing several lettuce cultivars under NFT system using seedlings produced in phenolic foam trays $\left(8 \mathrm{~cm}^{3}\right.$ cell $\left.^{-1}\right)$ were found 27 leaves plant $^{-1}$ for all the studied varieties at 30 DAT (Magalhães et al., 2010). Using the same cell volume and harvest season at 39 DAT for Grand Rapids type lettuce, the authors observed 26.4 leaves plant ${ }^{-1}$ (Casaroli et al., 2003).

In the first harvest, fresh matter of aerial part was $96 \mathrm{~g} \mathrm{plant}^{-1}\left(10 \mathrm{~cm}^{3}\right.$ cell $\left.^{-1}\right)$ and $237 \mathrm{~g} \mathrm{plant}^{-1}\left(50 \mathrm{~cm}^{3}\right.$ cell $\left.^{-1}\right)$, a difference of $59.5 \%$, whereas at $29 \mathrm{DAT}$ the difference between the smaller and larger cell volume was $194 \mathrm{~g} \mathrm{plant}^{-1}$ (an increase of 56\%) (Figure 2A). Ortiz et al. (2015), growing lettuce in soil, from seedlings produced in trays with 10,12 and $14 \mathrm{~cm}^{3}$ cell $^{-1}$, verified an increase of fresh matter of aerial part according to an increase of cell volume. The fresh matter of lettuce to be commercialized may vary according to the cultivar, 
spacing used for cultivation, techniques and growing time. Santi et al. (2013) stated an average of fresh matter from 156.5 to $399.4 \mathrm{~g} \mathrm{plant}^{-1}$ for cripshead lettuce.
Production of lettuce in trays with 40 and $50 \mathrm{~cm}^{3}$ cell-1 allowed an early harvest ( 7 days) compared to the lettuce produced in volumes of 10 to $20 \mathrm{~cm}^{3}$ cell-1 $^{-1}$ (Figure 2A). A decrease

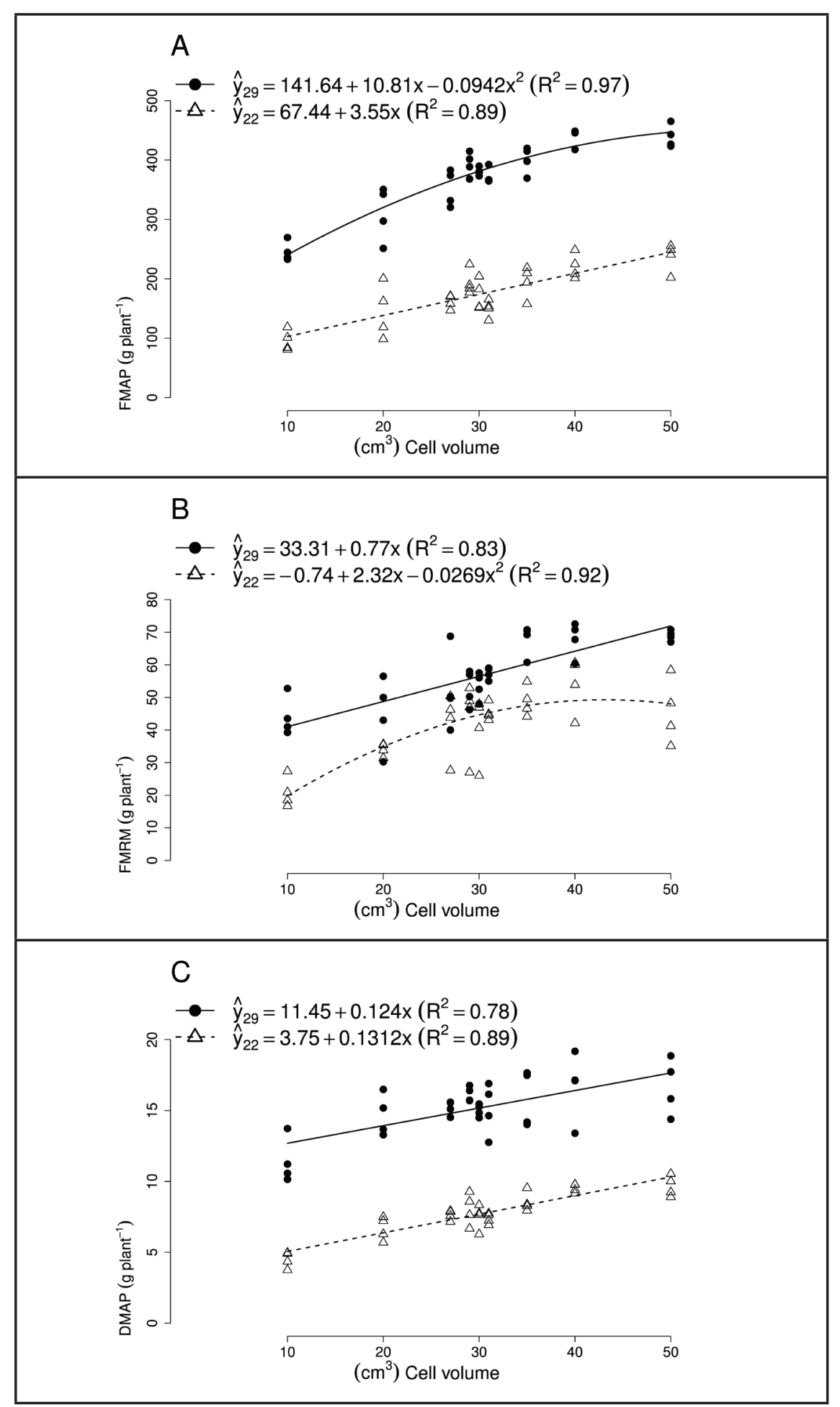

Figure 2. $A=$ Fresh matter of aerial part $\left(\right.$ FMAP g plant $\left.{ }^{-1}\right)$; $B=$ Fresh matter of root mass

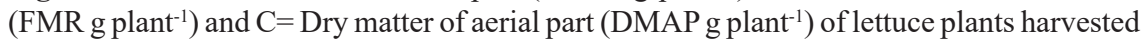
at 22 and 29 DAT grown in NFT hydroponic system using seedlings produced in trays with different volumes per cell. Araras, UFSCar, 2016. of fresh matter of aerial part at 29 DAT in volumes of 40 and $50 \mathrm{~cm}^{3}$ cell-1 $^{-1}$ was noticed, probably caused by a higher number of senescent leaves, since they presented dehydration and did not contribute to an increase in fresh matter of aerial part. Blat et al. (2011) found fresh matter of aerial part of $130.6 \mathrm{~g}$ plant $^{-1}$ in lettuce grown in trays with $8 \mathrm{~cm}^{3}$ cell $^{-1}$ at 28 DAT. Comparing the two harvests, the seedling production in larger volume $\left(50 \mathrm{~cm}^{3}\right.$ cell $\left.^{-1}\right)$ allowed harvest of approximately 16 cycles year ${ }^{-1}$; on the other hand, with the volume of 10 $\mathrm{cm}^{3}$ cell $^{-1}$, harvest decreased to 12 cycles year $^{-1}$. Besides an increase of annual production, the seedling production with larger cell volume ${ }^{-1}$ reduces the number of transplant from two to one, makes the intermediate phase unnecessary, reduces production costs, increases profitability and quality of harvested plants due to fewer injuries to root system at the time of transplant into NFT system.

Fresh matter of root was found in lettuce grown in trays with 10 and 20 $\mathrm{cm}^{3}$ cell $^{-1}$, with 44.12 and 44.94 g plant $^{-1}$, respectively, and greatest mass of 67.81 , 67.84 and 67.25 g plant $^{-1}$ of plant roots produced in trays with 35,40 and 50 $\mathrm{cm}^{3}$ cell $^{-1}$, respectively (Figure 2B). Casaroli et al. (2003), using trays with $8 \mathrm{~cm}^{3}$ cell $^{-1}$ and growing several Grand Rapids type lettuce varieties under NFT which remained 9 days in intermediate phase, observed root fresh matter of $50.94 \mathrm{~g}$ at 30 DAT.

Comparing fresh matter of aerial part and dry matter of aerial part at 22 DAT, lettuce plants produced in trays with 50, $40,35,31,30,29,27,20$ and $10 \mathrm{~cm}^{3}$ cell $^{-1}$ were composed of dry matter of aerial part 4.0, 4.3, 4.3, 4.9, 4.3, 4.1, 4.7, 4.6 and $4.6 \%$, respectively. A decrease in shoot dry mass accumulation at 22 to 29 DAT was noticed. For the harvest at 29 DAT spacing $0.25 \mathrm{~m}$ between profiles and $0.30 \mathrm{~m}$ between plants, was not sufficient to increase the shoot dry mass. Evaluating the harvest seasons (35 and 42 DAT) for chicory, a decrease was verified in the transformation from the fresh matter of aerial part to dry matter of aerial part in the second harvest (42 DAT), regardless of the tray used for cultivation $\left(40,16\right.$ and $12 \mathrm{~cm}^{3}$ cell $\left.^{-1}\right)$ (Reghin et al., 2007). Ortiz et al. (2015) 


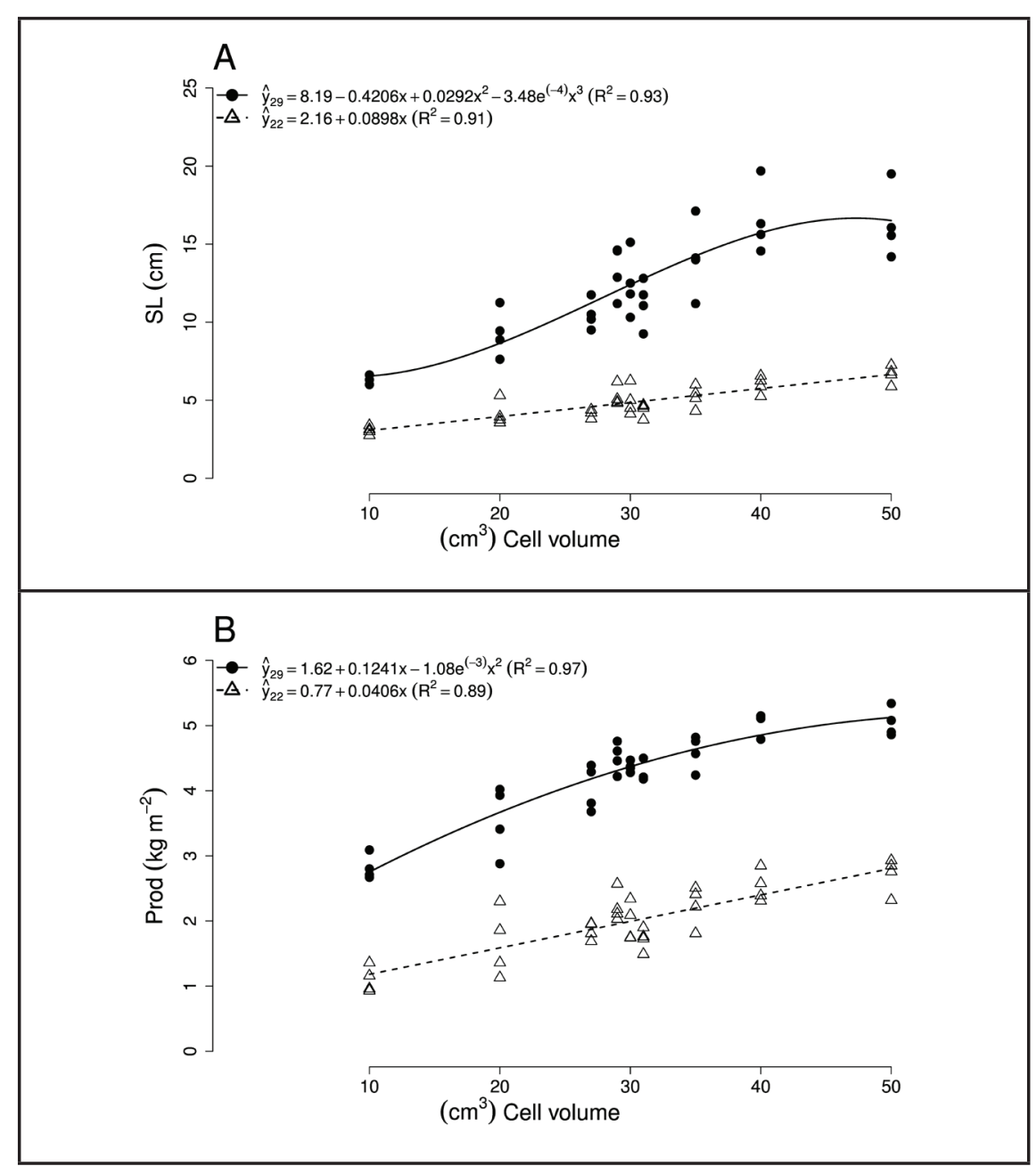

Figure 3. $\mathrm{A}=$ Stem length $\left(\mathrm{SL} \mathrm{cm} \mathrm{plant}{ }^{-1}\right)$ and $\mathrm{B}=$ Productivity $\left(\mathrm{kg} \mathrm{m}^{-2}\right)$ of lettuce plants harvested at 22 and 29 DAT grown in NFT hydroponic system using seedlings produced in trays with different volumes per cell. Araras, UFSCar, 2016.

reported that, in lettuce cultivation, an increase in shoot dry mass according to an increase of cell volume (volume of cell), using trays with 14,12 and $10 \mathrm{~cm}^{3}$ cell $^{-1}$ was observed. Using cells of 18.75 $\mathrm{cm}^{3}$ cell $^{-1}$ in phenolic foam, Luz et al. (2006) observed, for lettuce, shoot dry mass of $11.95 \mathrm{~g} \mathrm{plant}^{-1}$, similar to shoot dry mass of the treatments with volumes of $10 \mathrm{~cm}^{3}$ cell- $^{-1}\left(11.42 \mathrm{~g} \mathrm{plant}^{-1}\right)$ and 20 $\mathrm{cm}^{3}$ cell $^{-1}\left(12.42 \mathrm{~g} \mathrm{plant}^{-1}\right)$, found in this study at 29 DAT (Figure 2C).

In the first evaluation, shorter stem length $\left(3.06 \mathrm{~cm} \mathrm{plant}^{-1}\right)$ was found in plants produced in cells with $10 \mathrm{~cm}^{3}$ cell $^{-1}$ volume and longer stem with 50 $\mathrm{cm}^{3}$ cell $^{-1}$ (6.64 $\mathrm{cm}$ plant $\left.{ }^{-1}\right)$, without bolting. However, at 29 DAT, the lettuce produced in trays with volume of 40 and $50 \mathrm{~cm}^{3}$ cell $^{-1}$ showed stem measuring 16.54 and $16.32 \mathrm{~cm}$, respectively (Figure
3A), already bolted due to elongation of the stem with the beginning of the floral primordium formation (Silva et al., 1999). Early lettuce bolting hinders commercialization due to bitter taste of the leaves (Filgueira, 2008). Gualberto et al. (1999), using looseleaf type seedlings produced in trays with 288 cells (without mentioning cell volume) transplanted into NFT in spacing $25 \times 30$ $\mathrm{cm}$, found stem of $9.82 \mathrm{~cm}$ plant $^{-1}$ at 24 DAT, differing from the result, $3.06 \mathrm{~cm}$ plant $^{-1}$, found for the smallest volume of this study $\left(10 \mathrm{~cm}^{3}\right.$ cell $\left.^{-1}\right)$. In crisphead lettuce cultivation under NFT system, using seedlings produced in phenolic foam and transplanted into spacing $25 \times 25 \mathrm{~cm}$, Sediyama et al. (2009) found stem of $8.35 \mathrm{~cm} \mathrm{plant}^{-1}$ at 27 DAT, similar to the result found at 29 DAT in this study, $8.12 \mathrm{~cm}$ plant $^{-1}$. Stem with
$15.34 \mathrm{~cm}$ plant ${ }^{-1}$ was obtained in lettuce 'Elisa' using seedlings produced in trays with 128 cells and transplanted into spacing of $25 \times 30 \mathrm{~cm}$, harvested at 32 DAT cultivated in soil under thermoreflective screen $30 \%$ (Diamante et al., 2013).

Lettuce productivity in volume of $10 \mathrm{~cm}^{3}$ cell $^{-1}$ was $1.49 \mathrm{~kg} \mathrm{~m}^{2}$ and 3.82 $\mathrm{kg} \mathrm{m}^{2}$ for harvests at 22 and 29 DAT, respectively, differing from the largest volume tray $\left(50 \mathrm{~cm}^{3}\right.$ cell $\left.^{-1}\right)$ in $42.8 \%$, in the first harvest and $55.85 \%$ in the second harvest (Figure 3B). The productivity of plants grown in trays with $27 \mathrm{~cm}^{3}$ cell $^{-1}$ $\left(2.51 \mathrm{~kg} \mathrm{~m}^{-2}\right)$ was exceeded by those recipients of upper volumes. Increasing substrate volume did not influence baby leaf lettuce productivity during four harvest seasons $(18,21,28,35$ and 42 days) (Oliveira et al., 2009), unlike the productivity obtained in this study, which gradual increase, up to 29 DAT. The productivity at 22 DAT of plants produced in volumes of 29 to $50 \mathrm{~cm}^{3}$ cell $^{-1}$ exceeded the productivity found in cultivation of Grand Rapids type lettuce 'Vera' in soil, which reaches $2.58 \mathrm{~kg} \mathrm{~m}^{-2}$ at 42 DAT (Meneses et al., 2016).

For most of the evaluated traits, the best lettuce development was obtained when seedlings were grown in trays with larger cell volume, being the better growth related to an increase of substrate volume. Intermediate phase was unnecessary and the reduction of transplant, from two to one, in treatments of 20 to $50 \mathrm{~cm}^{3}$ cell $^{-1}$, resulting in lower labor costs and shorter cycle. Using seedlings grown in trays with 40 and 50 $\mathrm{cm}^{3}$ cell $^{-1}$ made early harvest possible (in one week). Considering economic terms, the authors highlight that further studies should be carried out aiming to quantify this difference, mainly concerning early cultivation, purchasing trays and seedling production.

\section{REFERENCES}

ANDRIOLO, JL; ESPINDOLA, MCG; STEFANELLO, MO. 2003. Crescimento e desenvolvimento de plantas de alface provenientes de mudas com diferentes idades fisiológicas. Ciência Rural 33: 35-40.

APTA - Agência Paulista de Tecnologia dos Agronegócios. Ciência Agropecuária 
Paulista: Pesquisa e inovação gerando produtividade e qualidade de vida. Available at http://www.apta.sp.gov/. Accessed February 1, 2014.

BLAT, SF; SANCHEZ, SV; ARAÚJO, JAC; BOLONHEZI, D. 2011. Desempenho de cultivares de alface crespa em dois ambientes de cultivo em sistema hidropônico. Horticultura Brasileira 29: 135-138.

CAMPOS-VARGAS, R; SALTVEIT, ME. 2002. Involvement of putative chemical wound signals in the induction of phenolic metabolism in wounded lettuce. Physiologia Plantarum 114: 73-84.

CASAROLI, D; FAGAN, EB; SANTOS, OS; BONNECARRÊRE, RAG; FILHO, HN. 2003. Desempenho de onze cultivares de alface em duas formas diferentes de canais de cultivo, no sistema hidropônico. Revista da Faculdade de Zootecnia, Veterinária e Agronomia 10: 25-33.

DIAMANTE, MS; JÚNIOR, SS; INAGAKI, AM; SILVA, MB; DALLACORT, R. 2013. Produção e resistência ao pendoamento de alfaces tipo lisa cultivadas sob diferentes ambientes. Ciência Agronômica 44: 133-140.

FERREIRA，EB；CAVALCANTI，PP; NOGUEIRA, DA.2013. Experimental design package. Available at http://CRAN.R-project. org $/$ package $=$ ExpDes.pt

FILGUEIRA, FAR. 2008. Novo Manual de Olericultura. Viçosa: UFV. 421p.

FURLANI, PR. 1999. Hydroponic vegetable production in Brazil. São Paulo: Acta Horticulturae. 481: 777-778.

GOMES, FP. 2009. Curso de estatística experimental. Piracicaba: Fealq. 451p.

GUALBERTO, R; RESENDE, FV; BRAZ, LT.
1999. Competição de cultivares de alface sob cultivo hidropônico 'NFT' em três diferentes espaçamentos. Horticultura Brasileira 17: 155-158.

LUZ, JMQ; GUIMARÃES, STMR; KORNDÖRFER, GH. 2006. Produção hidropônica de alface em solução nutritiva com e sem silício. Horticultua Brasileira 24: 295-300.

MAGALHÃES, AG; MENEZES, D; RESENDE, LV; NETO, EB. 2010. Desempenho de cultivares de alface em cultivo hidropônico sob dois níveis de condutividade elétrica. Horticultura Brasileira 28: 316-320.

MAGGIONI, MS. 2014. Desenvolvimento de mudas de manjericão (Ocimum basilicum L.) em função do recipiente e do tipo e densidade de substratos. Revista Brasileira de Plantas Medicinais 16: 10-17.

MENESES, NB; MOREIRA, MA; SOUZA, IM; BIANCHINI, FG. 2016. Crescimento e produtividade de alface sob diferentes tipos de cobertura do solo.RevistaAgro@mbiente 10: 123-129.

MENEZES JÚNIOR, FOG; FERNANDES, HS; MAUCH, CR; SILVA, B. 2000. Caracterização de diferentes substratos e seu desempenho na produção de mudas de alface em ambiente protegido. Horticultura Brasileira 18: 164170.

MINAMI, K. 2010. Produção de mudas de alta qualidade. Piracicaba: Degaspari 440p.

OLIVEIRA, F; BAQUEIRO, LHR; ROCHA, MAV; TIVELLI, SW; PURQUERIO, LFV. 2009. Produção de baby leaf de alface em bandejas com diferentes volumes de células. Horticultura Brasileira 27: 3111-3115.
ORTIZ, TA; TAKAHASHI, LS; HORA, RC. 2015. Agronomic performance of lettuce produced in trays with different cell number field spacings. African Journal Of Agriculture 10: 1407-1411.

PRIMAVESI, A. 2002. Raiz: as propriedades físicas do solo e o enraizamento. In: PRIMAVESI, A (ed). A agricultura em regiões tropicais: manejo ecológico do solo. São Paulo: Nobel. p.46-51.

R CORE TEAM. 2015. R: A language and environment for statistical computing. Available at //www.R-project.org/

REGHIN, MY; OTTO, RF; OLINIK, JR; JACOBY, CFS. 2007. Produtividade da chicória (Cichorium endivia L.) em função de tipos de bandejas e idade de transplante de mudas. Ciência e Agrotecnologia 31: 739-747.

SALA, FC; COSTA, CP. 2012. Retrospectiva e tendência da alfacicultura brasileira. Horticultura Brasileira 30: 187-194.

SANTI,A; SCARAMUZZA, WLMP; NEUHAUS, A; DALLACORT, R; KRAUSE, W; TIEPPO, RC. 2013. Desempenho agronômico de alface americana fertilizada com torta de filtro em ambiente protegido. Horticultura Brasileira 31: 338-343.

SEDIYAMA, MAN; PEDROSA, MW; SALGADO, LT; PEREIRA, PC. 2009. Desempenho de cultivares de alface para cultivo hidropônico no verão e no inverno. Cientifica 37: 98-106.

SILVA, EC; LEAL, NR; MALUF, WR. 1999. Avaliação de cultivares de alface sob altas temperaturas em cultivo protegido em três épocas de plantio na região Norte Fluminense. Ciência e Agrotecnologia 23: 491-499.

\section{ERRATA}

We apologize for the wrong registration of author's names, on the article cited below, published in volume 36 number 3, July to September 2018, page 408-413:

LIMA, TJL; GAZAFFI, R; CECCHERINI, GJ; MARCHI, L; MARTINEZ, M; FERREIRA, CG; SALA, FC. 2018. Volume of cells on trays influences hydroponic lettuce production. Horticultura Brasileira 36: 408-413. DOI - http://dx.doi.org/10.1590/S0102-053620180320

The following author's names associated to DOI http://dx.doi.org/10.1590/S0102-053620180320 were incorrectly grouped. Where the names were registered as: Luana Marchi; Marcela Martinez
And grouped as: Camila G Ferreira; Fernando C Sala

\section{The author's names must be individualized.}

